\title{
EFFECT OF NPK AND HUMIC ACID ON GROWTH, FLOWERING AND CHEMICAL COMPOSITION OF (BLUE SAKE) ERANTHEUMUM PULCHELLUM ANDREWS PLANT
}

\author{
NOFAL, E. M. S. ${ }^{1}$ - MENESI, F. A. ${ }^{1}$ - El-BABly, S. Z. ${ }^{2}-$ ABd El RAHMAN, M. ${ }^{2}$ \\ ${ }^{l}$ Hort. Dept., Fac. Agric., Kafr ELSheikh Univ., Kafr El-Sheik, Egypt \\ ${ }^{2}$ Sakha Exper. Stat., Hort. Res. Inst., Kafr El-Sheik, Egypt \\ *Corresponding author \\ e-mail:ahmed.ebad@rocketmail.com \\ (Received $8^{\text {th }}$ Jul 2019; accepted $23^{\text {rd }}$ Jan 2020)
}

\begin{abstract}
In this study the treatments were carried out as follows: Control; Full dose of NPK containing 6 $\mathrm{g}$ ammonium sulphate $(20.5 \% \mathrm{~N})+4 \mathrm{~g}$ calcium super phosphate $\left(15.5 \% \mathrm{P}_{2} \mathrm{O}_{5}\right)+3 \mathrm{~g}$ potassium sulphate $\left(48.5 \% \mathrm{~K}_{2} \mathrm{O}\right)$ to $8 \mathrm{~kg}$ soil in the pot; Half NPK dose; Half NPK dose $+50 \mathrm{ppm}(\mathrm{HA})$; Half NPK dose $+100 \mathrm{ppm}$ (H.A.); Half NPK dose $+150 \mathrm{ppm}$ (H.A.); as well as (H.A.) at 50,100 and $150 \mathrm{ppm}$. The obtained results showed that most treatments resulted significantly taller plants, higher branch and leaf plural, wider leaf area compared to control with $1 / 2 \mathrm{NPK}+150 \mathrm{ppm}$ (H.A.) treatment providing the best results as this treatment gave also the high significant. Additionally, this treatment caused significantly the earliest flowering with the longest flower stem, widest flower diameter, number of flowers per plant as well as the heaviest fresh and dry weight of flowers. Most treatments gave significantly higher total chlorophyll in the leaves than the control with the superiority of the treatment of $1 / 2 \mathrm{NPK}+150 \mathrm{ppm}$ (H.A.) followed by the treatment of NPK alone with non-significant differences in between. $\mathrm{N}$ ratio in the leaves significantly increased over control in most treatments and especially for the treatment of $1 / 2$ NPK $+150 \mathrm{ppm}$ (H.A.). P ratio in the leaves were significantly the highest as a result of the NPK treatment with no other additives. While the highest $\mathrm{K}$ ratio resulted from the treatment of either 100 or150 ppm (H.A.) without significant differences in between. However, the treatment of $1 / 2 \mathrm{NPK}+150$ ppm (H.A.) is recommended to obtain high quality plants.
\end{abstract}

Keywords: potassium humate; $N, P$ and $K$ fertilization; chemical fertilization; Erantheumum pulchellum

\section{Introduction}

Chemical fertilization provides nutrients optimal for plant growth and development. The essential nutrients in the fertilizers are nitrogen, phosphorous and potassium (NPK). The most important major nutrient is nitrogen $(\mathrm{N})$ which partakes in many compounds in the plant such as amino acids, proteins, chlorophylls, hormones, alkaloids and enzymes. Phosphorus (P) partakes in phospholipids, DNA, RNA and metabolism of fats. Potassium $(\mathrm{K})$ regulates water condition within the plant cell and water loss by transpiration as a catalyst and condensing agent of complex substances through its active properties (Devlin, 1975) and potassium has a main role in plant metabolism such as photosynthesis, translocation of photosynthates, water relation as well as enzyme activation. Although, potassium is not a constituent of any plant structures or compounds, but it plays a part in many important regulatory roles in the plant, i.e. osmo-regulation process, regulation of plant stomata and water use, translocation of sugars and formation of carbohydrates, energy status of the plant, the regulation of enzyme activities, protein synthesis and many other processes needed to sustain plant growth and reproduction (Hasio and Lauchli, 1986). 
Humic acid (HA), called humin materials widely consists of a part of soil organic matter (65-70\%) (Stott and Martin, 1990). It is a potential natural resource that can be utilized to increase growth, nutrient availability and yield (Sharif et al., 2002). It has direct and indirect effects on plant growth due to roles of humic acid (Pal and Biswas, 2005). Humic acid treatments improve soil aggregation, structure, water permeability, air conditioning, fertility, moisture-holding capacity. It constitutes a stable fraction of carbon (C), thus regulating the carbon cycle and releasing of nutrients, including $\mathrm{N}, \mathrm{P}$ and S (Stevenson,1994) and improving nutrients uptake and hormonal effects (Nikbakht et al., 2008).

\section{Erantheumum pulchellum Andrews (syn Daedalacanthus nervosum R) blue sake}

The 7.5 to $15.3 \mathrm{~cm}$-long flower spikes are borne above the large, rounded and prominently veined leaves. Leaves are large, dark green, simple, opposite and leaf blade length arrives 5 to $10 \mathrm{~cm}$. Fruit shape is oval and its length is less than $12.5 \mathrm{~cm}$. It is used in flower beds. It is popular with gardeners because of the spikes of flowers that are bright gentian blue - an unusual color in the tropics (Edward, 1999) as illustrated in Figure 1.

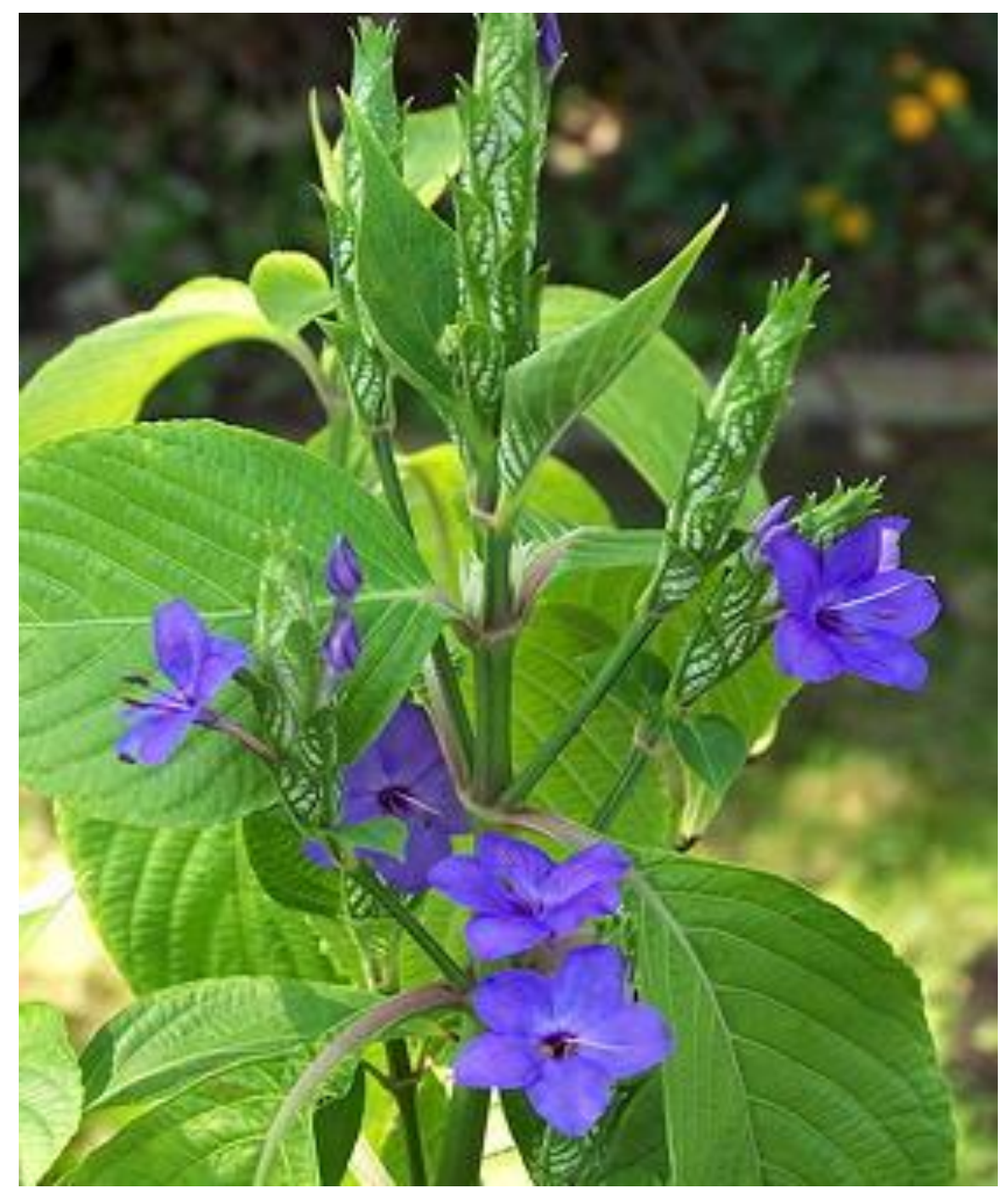

Figure 1. Erantheumum pulchellum Andrews plant 
The aim of this work was to study the effect of (NPK) nitrogen, phosphorus and potassium and humic acid (HA) on the growth, flowering and chemical composition of the plant and try to obtain the synergistic effect of HA to partly replace the risk of pollution to environments by chemical fertilization. Hence there was no need for the treatment of NPK (full dose) + HA.

\section{Martials and methods}

A series of pot experiments in the open field were conducted during 2014/2015 and 2015/2016 seasons in Hort. Dept., Agric. Fac., Kafr El-Sheik Univ. Egypt. The site is located at $31^{\circ} 07 \mathrm{~N}$ latitude and $30^{\circ} 57 \mathrm{E}$ longitude with an elevation of about $6 \mathrm{~m}$ above mean sea level. The climatic conditions of the study area are provided in Table 1.

Table 1. Monthly air temperature (Max., Min. and Mean ${ }^{\circ} \mathrm{C}$ ), relative humidity ( $\mathrm{RH} \%$ ), at the experimental site during the two growing seasons of 2014/2015 and 2015/2016. (Source Sakha Agricultural Research Station, Kafr El-Sheikh Governorate, Egypt)

\begin{tabular}{c|c|c|c|c|c|c|c|c}
\hline Season & \multicolumn{4}{|c|}{$\mathbf{2 0 1 4 / 2 0 1 5}$} & \multicolumn{3}{c|}{ 2015/2016 } & \multirow{2}{*}{ RH\% } \\
\hline \multirow{2}{*}{ Month } & \multicolumn{3}{|c|}{ Air Temp } & \multicolumn{3}{c}{ Air Temp } \\
\cline { 2 - 4 } \cline { 6 - 7 } & Max & Min & Mean & & Max & Min & Mean & \\
\hline September & 32.49 & 20.76 & 26.58 & 69.89 & 34.6 & 22.8 & 28.7 & 64.6 \\
October & 29.75 & 18.75 & 24.25 & 67.16 & 22.9 & 20.06 & 21.75 & 67.1 \\
November & 24.3 & 13.79 & 19.04 & 74.15 & 24.4 & 14.42 & 19.41 & 75.6 \\
December & 22.27 & 9.72 & 16.00 & 76.05 & 19.7 & 8.36 & 14.03 & 77.9 \\
January & 18.79 & 6.46 & 12.63 & 74.6 & 18.4 & 6.35 & 12.38 & 74.05 \\
February & 19.01 & 7.69 & 13.35 & 74.8 & 22.58 & 9.35 & 15.96 & 69.05 \\
Mars & 22.69 & 11.69 & 17.19 & 70.6 & 25.5 & 11.6 & 18.55 & 69.9 \\
April & 25.64 & 13.7 & 19.67 & 63.4 & 30.03 & 18.62 & 24.33 & 61.7 \\
May & 30.19 & 18.79 & 24.49 & 61.7 & 30.04 & 22.8 & 26.42 & 58.4 \\
June & 30.85 & 21.4 & 26.13 & 65 & 33.6 & 26.3 & 29.95 & 61.15 \\
July & 33.0 & 22.4 & 27.7 & 70.0 & 33.7 & 26.1 & 29.9 & 69.75 \\
Augustus & 35.1 & 25.0 & 30.05 & 67.8 & 33.6 & 26.0 & 29.8 & 70.3 \\
\hline
\end{tabular}

The aim was to study the effect of $\mathrm{N}, \mathrm{P}$ and $\mathrm{K}$ fertilization and humic acid foliar spray on the growth, flowering and chemical composition of a local variety of Eranthemum pullchellum Vahl R.BR. The cuttings of one-year-old plants of $10 \mathrm{~cm}$ length were planted in $20 \mathrm{~cm}$ diameter clay pots filled with about $8 \mathrm{~kg}$ clayey soil as one plant/pot commencing on the $1^{\text {st }}$ September till September of the next year. The plants were treated as follows: 1-Control, 2-Full dose of NPK containiing $6 \mathrm{~g}$ ammonium sulphate $(20.5 \% \mathrm{~N})+4 \mathrm{~g}$ calcium super phosphate $(15.5 \% \mathrm{P} 2 \mathrm{O} 5)+3 \mathrm{~g}$ potassium sulphate $(48.5 \% \mathrm{~K} 2 \mathrm{O})$, 3-Half NPK dose, 4- Half NPK dose $+50 \mathrm{ppm}$ humic acid (HA), 5- Half NPK dose +100 ppm humic acid (HA), 6- Half NPK dose +150 ppm humic acid (HA), 7- 50 ppm humic acid (HA), 8- 100 ppm humic acid (HA) and 9- 150 ppm humic acid (HA). The treatments were replicated three times involving 9 plants in a complete randomized design. NPK fertilizer was drench-applied as calcium super phosphate at preparing the soil, while $\mathrm{N}$ and $\mathrm{K}$ were monthly applied after one month from planting. HA was foliar applied monthly after one month from planting as the 
plants were run-off sprayed. The watering was every three days at summer and weekly in winter. The following data were recorded after one year, plant height $(\mathrm{cm})$, number of branches, number of leaves/plant, leaf area as mean of 3 leaves in the middle part of the plant $\left(\mathrm{cm}^{2}\right)$ by using CI-202 portable laser leaf area meter (cidb10-science) made in USA, WWW.CID-INC.COM, fresh and dry weights of vegetative parts per plant (g), root length of the longest root $(\mathrm{cm})$, fresh and dry weight of the roots per plant $(\mathrm{g})$ after removing soil by water, flowering date (days) as the first flower showed color on the plant, number of flowers per plant, diameters of flower $(\mathrm{cm})$, fresh and dry weights of flowers/plant $(\mathrm{g})$ and flower stem length $(\mathrm{cm})$. As for chemical composition total chlorophyll in leaf of the middle part of the plant was carried out according to Minolta chlorophyll method SPAD-SO (Yadava, 1986). Nitrogen\% was determined by modified micro Kjeldahle method as described by Black (1983)

Phosphorus was determined colorimetrically as the method described by King (1951) while, potassium was estimated using the flame photometer according to Jackson (1967). Means of treatments were compared by Duncan's multiple range test (Duncan, 1955) at a level of 5\% probability according to Sendecor and Cochran (1980).

\section{Results}

Effect of treatments of NPK and humic acid on vegetative growth, flowering and chemical composition parameters of the plants

\section{A. Vegetative growth, plant height, No. branches, No. leaves and leaf area}

Data presented in Table 2 showed that in most cases treatments of NPK and humic acid significantly increased plant height and gave more branches than the control in both seasons. The significantly tallest plants and highest number of branches in the first season resulted from the treatment of $1 / 2 \mathrm{NPK}+150 \mathrm{ppm}$ humic acid. In the second season, this treatment extended the simulative effect in addition to the treatment of NPK alone without significant differences in between.

The same table revealed that most treatments gave significantly more leaf number and widest leaf area per plant compared to control in the two seasons with the superiority of treatment of $1 / 2 \mathrm{NPK}+150 \mathrm{ppm}$ humic acid in both seasons. In the second season, this treatment was partaken with the treatment of $1 / 2 \mathrm{NPK}+100 \mathrm{ppm}$ humic acid (HA) and NPK alone without significant differences.

\section{B. Fresh and dry weight of vegetative parts}

Data presented in Table 3 revealed that most treatments gave significantly heavier fresh and dry weights than control in the two seasons. The significantly heaviest fresh and dry weight in the first season resulted from the treatment of $1 / 2 \mathrm{NPK}+150 \mathrm{ppm}$ humic acid (HA). In the second season, this resulted from the treatment of NPK and the treatment of $1 / 2 \mathrm{NPK}+150 \mathrm{ppm}$ humic acid (HA) without significant differences.

\section{Root parameters}

Data of the root length No. roots/plant fresh and dry weight of roots are presented in Table 4. Data exhibited that most treatments significantly increased root length over control in the first season as the significantly longest roots and highest roots number/plant resulted from the treatment of $1 / 2 \mathrm{NPK}+150 \mathrm{ppm}$ humic acid (HA) 
followed by the treatments of $1 / 2 \mathrm{NPK}+50 \mathrm{ppm}$ humic acid (HA), treatment of $1 / 2 \mathrm{NPK}$ +100 ppm humic acid (HA) without significant differences. In the second season, all treatments significantly increased root length when compared to the control and the significantly longest roots resulted from the treatment of $1 / 2$ NPK $+150 \mathrm{ppm}$ humic acid (HA) followed by the treatment of NPK alone without significant differences.

Table 2. Effect of NPK and humic acid treatments on some vegetative growth characters of Erantheumum pulchellum Andrews in two seasons

\begin{tabular}{|c|c|c|c|c|}
\hline Treatments & $\begin{array}{l}\text { Plant height } \\
(\mathrm{cm})\end{array}$ & $\begin{array}{c}\text { No. of } \\
\text { branches/plant }\end{array}$ & $\begin{array}{c}\text { No. of } \\
\text { leaves/plant }\end{array}$ & $\begin{array}{l}\text { Leaf area } \\
\quad\left(\mathrm{cm}^{2}\right)\end{array}$ \\
\hline \multicolumn{5}{|c|}{$1^{\text {st }}$ season } \\
\hline Control & $65.00 \mathrm{e}$ & $1.00 \mathrm{~b}$ & $27.00 \mathrm{~d}$ & $53.30 \mathrm{~d}$ \\
\hline NPK & $119.67 \mathrm{c}$ & $2.00 \mathrm{a}$ & $68.00 \mathrm{~b}$ & $70.00 \mathrm{c}$ \\
\hline $1 / 2 \mathrm{NPK}$ & $104.00 \mathrm{~d}$ & $1.67 \mathrm{ab}$ & $58.00 \mathrm{~b}$ & $51.73 \mathrm{~d}$ \\
\hline $1 / 2 \mathrm{NPK}+50 \mathrm{ppm}$ humic acid (HA) & $109.00 \mathrm{~d}$ & $1.67 \mathrm{ab}$ & $62.00 \mathrm{~b}$ & $55.70 \mathrm{~d}$ \\
\hline $1 / 2 \mathrm{NPK}+100 \mathrm{ppm}$ humic acid (HA) & $131.67 \mathrm{~b}$ & $2.00 \mathrm{a}$ & $68.00 \mathrm{~b}$ & $90.30 \mathrm{~b}$ \\
\hline $1 / 2 \mathrm{NPK}+150 \mathrm{ppm}$ humic acid (HA) & $159.00 \mathrm{a}$ & $2.00 \mathrm{a}$ & $89.00 \mathrm{a}$ & $120.70 \mathrm{a}$ \\
\hline 50 ppm humic acid (HA) & $68.33 \mathrm{e}$ & $1.00 \mathrm{~b}$ & $47.00 \mathrm{c}$ & $41.93 \mathrm{~d}$ \\
\hline 100 ppm humic acid (HA) & $70.33 \mathrm{e}$ & $1.33 \mathrm{ab}$ & $42.67 \mathrm{c}$ & $48.06 \mathrm{~d}$ \\
\hline 150 ppm humic acid (HA) & $73.67 \mathrm{e}$ & $1.67 \mathrm{ab}$ & $29.33 \mathrm{~d}$ & $44.80 \mathrm{~d}$ \\
\hline Mean & 100.07 & 1.60 & 54.62 & 64.09 \\
\hline \multicolumn{5}{|c|}{$2^{\text {nd }}$ season } \\
\hline Control & $68.00 \mathrm{~d}$ & $1.33 \mathrm{~b}$ & $17.00 \mathrm{~d}$ & $63.83 \mathrm{~cd}$ \\
\hline NPK & $103.67 \mathrm{a}$ & $2.00 \mathrm{ab}$ & $95.00 \mathrm{a}$ & $112.63 \mathrm{a}$ \\
\hline $1 / 2 \mathrm{NPK}$ & $88.00 \mathrm{c}$ & $1.67 \mathrm{~b}$ & $54.67 \mathrm{~b}$ & $84.16 b$ \\
\hline $1 / 2 \mathrm{NPK}+50 \mathrm{ppm}$ humic acid (HA) & $94.00 \mathrm{bc}$ & $3.00 \mathrm{a}$ & $62.33 \mathrm{~b}$ & $107.26 \mathrm{a}$ \\
\hline $1 / 2 \mathrm{NPK}+100 \mathrm{ppm}$ humic acid (HA) & $99.00 \mathrm{ab}$ & $3.00 \mathrm{a}$ & $95.00 \mathrm{a}$ & $98.63 \mathrm{a}$ \\
\hline $1 / 2 \mathrm{NPK}+150 \mathrm{ppm}$ humic acid (HA) & $107.33 \mathrm{a}$ & $1.67 \mathrm{~b}$ & $108.67 \mathrm{a}$ & $108.57 \mathrm{a}$ \\
\hline 50 ppm humic acid (HA) & $73.33 \mathrm{~d}$ & $1.00 \mathrm{~b}$ & $35.00 \mathrm{c}$ & $77.70 \mathrm{bc}$ \\
\hline 100 ppm humic acid (HA) & $71.33 \mathrm{~d}$ & $1.67 \mathrm{~b}$ & $26.67 \mathrm{~cd}$ & $59.40 \mathrm{~d}$ \\
\hline 150 ppm humic acid (HA) & $67.00 \mathrm{~d}$ & $1.67 \mathrm{~b}$ & $16.67 \mathrm{~d}$ & $74.70 \mathrm{bc}$ \\
\hline Mean & 85.74 & 1.88 & 56.77 & 87.43 \\
\hline
\end{tabular}

Means within a column having the same letters are not significantly different according to Duncan's multiple range test

Data showed clearly that most treatments gave significantly heavier fresh and dry weight of roots than the control in both seasons. The significantly heaviest value of roots weight resulted from the treatment of $1 / 2 \mathrm{NPK}+150 \mathrm{ppm}$ humic acid (HA), followed with non- significant differences by the treatment of NPK alone. The results were similar in the second season but the significantly highest value resulted from the treatment of NPK alone followed with non-significant differences by the treatment of $1 / 2 \mathrm{NPK}+150 \mathrm{ppm}$ humic acid (HA). 
Table 3. Effect of NPK and humic acid (HA) treatments on fresh and dry weights of vegetative parts of Erantheumum pulchellum Andrews in two seasons

\begin{tabular}{|c|c|c|}
\hline Treatments & $\begin{array}{c}\text { Fresh weight of vegetative plant } \\
\text { parts (g) }\end{array}$ & $\begin{array}{c}\text { Dry weight of vegetative } \\
\text { plant parts (g) }\end{array}$ \\
\hline \multicolumn{3}{|c|}{$1^{\text {st }}$ season } \\
\hline Control & $36.00 \mathrm{f}$ & $24.83 \mathrm{~d}$ \\
\hline NPK & $99.33 \mathrm{bc}$ & $51.50 \mathrm{a}$ \\
\hline $1 / 2 \mathrm{NPK}$ & $86.33 \mathrm{~cd}$ & $42.67 \mathrm{~b}$ \\
\hline $1 / 2 \mathrm{NPK}+50 \mathrm{ppm}$ humic acid & $88.00 \mathrm{~cd}$ & $43.30 \mathrm{~b}$ \\
\hline $1 / 2 \mathrm{NPK}+100 \mathrm{ppm}$ humic acid & $115.67 \mathrm{~b}$ & $43.70 \mathrm{~b}$ \\
\hline $1 / 2 \mathrm{NPK}+150 \mathrm{ppm}$ humic acid & $244.67 \mathrm{a}$ & $56.50 \mathrm{a}$ \\
\hline $50 \mathrm{ppm}$ humic acid & $67.33 \mathrm{de}$ & $36.23 \mathrm{bc}$ \\
\hline 100 ppm humic acid & $56.00 \mathrm{ef}$ & $31.40 \mathrm{~cd}$ \\
\hline 150 ppm humic acid & $35.67 \mathrm{f}$ & $26.50 \mathrm{~d}$ \\
\hline Mean & 92.11 & 39.62 \\
\hline \multicolumn{3}{|c|}{$2^{\text {nd }}$ season } \\
\hline Control & $25.77 \mathrm{~d}$ & $16.13 \mathrm{f}$ \\
\hline NPK & $130.93 \mathrm{a}$ & $48.23 \mathrm{c}$ \\
\hline $1 / 2 \mathrm{NPK}$ & $60.63 \mathrm{c}$ & $38.30 \mathrm{~d}$ \\
\hline $1 / 2 \mathrm{NPK}+50 \mathrm{ppm}$ humic acid & $64.93 \mathrm{c}$ & $29.00 \mathrm{e}$ \\
\hline $1 / 2 \mathrm{NPK}+100 \mathrm{ppm}$ humic acid & $100.00 \mathrm{~b}$ & $60.83 \mathrm{~b}$ \\
\hline $1 / 2 \mathrm{NPK}+150 \mathrm{ppm}$ humic acid & $126.40 \mathrm{a}$ & $74.17 \mathrm{a}$ \\
\hline $50 \mathrm{ppm}$ humic acid & $26.73 \mathrm{~d}$ & $15.87 \mathrm{f}$ \\
\hline 100 ppm humic acid & $22.67 \mathrm{de}$ & $13.00 \mathrm{f}$ \\
\hline 150 ppm humic acid & $16.47 \mathrm{e}$ & $8.00 \mathrm{~g}$ \\
\hline Mean & 63.83 & 33.72 \\
\hline
\end{tabular}

Means within a column having the same letters are not significantly different according to Duncan's multiple range test

\section{Flowering characters}

Data presented in Table 5 showed that the precocity of flowering in both seasons was for the treatment of $1 / 2$ NPK +150 ppm humic acid (HA) followed by NPK alone with non-significant differences. The previous promotive effect of these treatments was extended to the other flowering parameters. The stimulatory effect of NPK on flowering is well known as nitrogen is a main constituent of chlorophyll leading to effective characteristic as flower stem length, flower diameter, number of flowers per plant and fresh and dry weights of flower registering the significantly highest values when compared to control and other treatments. A few exceptions were gained for the treatment of $1 / 2 \mathrm{NPK}+100 \mathrm{ppm}$ humic acid giving values close to the previous treatments in the criteria of fresh and dry weights of flower.

\section{E. Chemical composition of plants}

Data of the effect of NPK treatment and humic acid on total chlorophyll, nitrogen, phosphorus and potassium ratio are presented in Table 6, as revealed the significantly highest values of total chlorophyll resulted from the treatment of $1 / 2 \mathrm{NPK}+150 \mathrm{ppm}$ 
humic acid (HA) followed by the treatment of NPK alone. with non- significant differences. It is apparent that most treatments of either NPK + humic acid or NPK alone increased total chlorophyll in the leaves of plant over control in both seasons. The superiority was for the treatments of $1 / 2 \mathrm{NPK}+150 \mathrm{ppm}$ humic acid followed by the other treatments of NPK alone or with humic acid with non-significant differences in most cases.

Table 4. Effect of NPK and humic acid treatments on some rooting characters and fresh and dry weight roots of Erantheumum pulchellum Andrews in two seasons

\begin{tabular}{|c|c|c|c|c|}
\hline Treatments & $\begin{array}{l}\text { Root length } \\
(\mathrm{cm})\end{array}$ & $\begin{array}{c}\text { No. of roots } \\
\text { plant }\end{array}$ & \begin{tabular}{|c|} 
Fresh weight \\
of roots (g)
\end{tabular} & $\begin{array}{l}\text { Dry weight } \\
\text { of roots }(\mathrm{g})\end{array}$ \\
\hline \multicolumn{5}{|c|}{$1^{\text {st }}$ season } \\
\hline Control & $20.67 \mathrm{c}$ & $16.33 \mathrm{e}$ & $14.33 \mathrm{~cd}$ & $3.83 \mathrm{c}$ \\
\hline NPK & $22.00 \mathrm{bc}$ & $22.33 \mathrm{~cd}$ & $22.33 \mathrm{ab}$ & $5.03 \mathrm{~b}$ \\
\hline $1 / 2 \mathrm{NPK}$ & $21.33 \mathrm{c}$ & $19.00 \mathrm{de}$ & $12.00 \mathrm{de}$ & $3.00 \mathrm{~d}$ \\
\hline $1 / 2 \mathrm{NPK}+50 \mathrm{ppm}$ humic acid (HA) & $28.67 \mathrm{ab}$ & $24.67 \mathrm{c}$ & $18.33 \mathrm{bc}$ & $4.60 \mathrm{~b}$ \\
\hline $1 / 2 \mathrm{NPK}+100 \mathrm{ppm}$ humic acid (HA) & $26.67 \mathrm{ab}$ & $29.33 \mathrm{~b}$ & $19.00 \mathrm{bc}$ & $5.03 \mathrm{~b}$ \\
\hline $1 / 2 \mathrm{NPK}+150 \mathrm{ppm}$ humic acid (HA) & $32.67 \mathrm{a}$ & $40.00 \mathrm{a}$ & $24.67 \mathrm{a}$ & $6.17 \mathrm{a}$ \\
\hline 50 ppm humic acid (HA) & $26.67 \mathrm{ab}$ & $17.00 \mathrm{e}$ & $11.16 \mathrm{de}$ & $3.06 \mathrm{~d}$ \\
\hline 100 ppm humic acid (HA) & $25.00 \mathrm{bc}$ & $17.00 \mathrm{e}$ & $8.47 \mathrm{e}$ & $3.16 \mathrm{~cd}$ \\
\hline 150 ppm humic acid (HA) & $25.00 \mathrm{bc}$ & $15.33 \mathrm{e}$ & $10.16 \mathrm{de}$ & $2.80 \mathrm{~d}$ \\
\hline Mean & 25.40 & 22.33 & 15.60 & 4.07 \\
\hline \multicolumn{5}{|c|}{$2^{\text {nd }}$ season } \\
\hline Control & $17.33 \mathrm{f}$ & $15.67 \mathrm{c}$ & $13.27 \mathrm{~d}$ & $3.04 \mathrm{c}$ \\
\hline NPK & $44.67 \mathrm{a}$ & $35.33 \mathrm{a}$ & $34.30 \mathrm{a}$ & $7.83 \mathrm{a}$ \\
\hline $1 / 2 \mathrm{NPK}$ & $33.33 \mathrm{bc}$ & $29.67 \mathrm{~b}$ & $24.33 \mathrm{c}$ & $5.60 \mathrm{~b}$ \\
\hline $1 / 2 \mathrm{NPK}+50 \mathrm{ppm}$ humic acid (HA) & $35.00 \mathrm{bc}$ & $33.33 \mathrm{~b}$ & $27.83 \mathrm{~b}$ & $6.17 \mathrm{~b}$ \\
\hline $1 / 2 \mathrm{NPK}+100 \mathrm{ppm}$ humic acid (HA) & $35.67 \mathrm{~b}$ & $32.67 \mathrm{~b}$ & $25.60 \mathrm{bc}$ & $5.23 \mathrm{~b}$ \\
\hline $1 / 2 \mathrm{NPK}+150 \mathrm{ppm}$ humic acid (HA) & $45.00 \mathrm{a}$ & $32.00 \mathrm{~b}$ & $32.73 \mathrm{a}$ & $7.80 \mathrm{a}$ \\
\hline 50 ppm humic acid (HA) & $29.67 \mathrm{~cd}$ & $14.33 \mathrm{c}$ & $11.33 \mathrm{~d}$ & $2.60 \mathrm{c}$ \\
\hline 100 ppm humic acid (HA) & $26.33 \mathrm{de}$ & $13.33 \mathrm{c}$ & $10.33 \mathrm{~d}$ & $2.77 \mathrm{c}$ \\
\hline 150 ppm humic acid (HA) & $24.00 \mathrm{e}$ & $15.00 \mathrm{c}$ & $10.17 \mathrm{~d}$ & $2.57 \mathrm{c}$ \\
\hline Mean & 32.33 & 27.93 & 21.09 & 4.89 \\
\hline
\end{tabular}

Means within a column having the same letters are not significantly different according to Duncan's multiple range test

The results presented in Table 6 showed that most treatments gave significantly higher $\mathrm{N}$ percentage than control in both seasons. The utmost highest values resulted from the treatments of NPK alone and $1 / 2$ NPK $+150 \mathrm{ppm}$ humic acid (HA) with nonsignificant differences in between. A somewhat similar trend was obtained for phosphorus percentage (P\%) with an exception for the treatment of $1 / 2 \mathrm{NPK}+100 \mathrm{ppm}$ humic acid giving values which non- significantly differ from the treatment of either NPK alone or $1 / 2$ NPK + 150 ppm humic acid.

For potassium percentage $(\mathrm{K} \%)$ a similar trend was obtained. but the treatment of $1 / 2$ NPK $+100 \mathrm{ppm}$ humic acid gave a value which did not differ from the treatments of NPK alone and $1 / 2$ NPK +150 ppm humic acid. 
Table 5. Effect of NPK and humic acid treatments on some flowering characters and their fresh and dry weights of Erantheumum pulchellum Andrews in two seasons

\begin{tabular}{|c|c|c|c|c|c|c|}
\hline Treatments & $\begin{array}{l}\text { No of days } \\
\text { to first } \\
\text { flower }\end{array}$ & $\begin{array}{c}\text { Flower } \\
\text { stem } \\
\text { length }(\mathrm{cm})\end{array}$ & $\begin{array}{c}\text { Flower } \\
\text { diameter } \\
(\mathbf{c m})\end{array}$ & $\begin{array}{c}\text { No. of } \\
\text { flowers/plant }\end{array}$ & $\begin{array}{c}\text { Fresh } \\
\text { weight of } \\
\text { flowers (g) }\end{array}$ & $\begin{array}{c}\text { Dry weight } \\
\text { of flowers } \\
\text { (g) }\end{array}$ \\
\hline Control & $311.00 \mathrm{a}$ & $4.03 \mathrm{e}$ & 4.07 ef & $10.00 \mathrm{~d}$ & $1.61 \mathrm{~d}$ & $1.10 \mathrm{e}$ \\
\hline NPK & $258.33 \mathrm{~d}$ & $5.90 \mathrm{~b}$ & $6.57 \mathrm{a}$ & $13.67 \mathrm{c}$ & $2.20 \mathrm{c}$ & $1.46 \mathrm{c}$ \\
\hline $1 / 2 \mathrm{NPK}$ & $272.67 \mathrm{c}$ & $4.87 \mathrm{~d}$ & $5.13 \mathrm{c}$ & $11.67 \mathrm{~cd}$ & $1.87 \mathrm{~cd}$ & $1.21 \mathrm{de}$ \\
\hline $1 / 2 \mathrm{NPK}+50 \mathrm{ppm}$ humic acid (HA) & $274.66 \mathrm{c}$ & $5.00 \mathrm{~d}$ & $5.43 \mathrm{bc}$ & $13.33 \mathrm{c}$ & $2.14 \mathrm{c}$ & $1.40 \mathrm{~cd}$ \\
\hline $1 / 2 \mathrm{NPK}+100 \mathrm{ppm}$ humic acid (HA) & $268.67 \mathrm{c}$ & $5.23 \mathrm{c}$ & $5.73 \mathrm{~b}$ & $17.00 \mathrm{~b}$ & $2.74 \mathrm{~b}$ & $1.72 \mathrm{~b}$ \\
\hline $1 / 2 \mathrm{NPK}+150 \mathrm{ppm}$ humic acid (HA) & $249.33 \mathrm{~d}$ & $6.53 \mathrm{a}$ & $6.53 \mathrm{a}$ & $22.00 \mathrm{a}$ & $3.54 \mathrm{a}$ & $2.24 \mathrm{a}$ \\
\hline 50 ppm humic acid (HA) & $294.00 \mathrm{~b}$ & $3.90 \mathrm{e}$ & $4.63 \mathrm{~d}$ & $12.33 \mathrm{~cd}$ & $1.99 \mathrm{~cd}$ & $1.06 \mathrm{e}$ \\
\hline 100 ppm humic acid (HA) & $277.00 \mathrm{c}$ & $3.87 \mathrm{e}$ & $4.20 \mathrm{e}$ & $11.33 \mathrm{~cd}$ & $1.82 \mathrm{~cd}$ & $1.01 \mathrm{e}$ \\
\hline 150 ppm humic acid (HA) & $273.67 \mathrm{c}$ & $3.80 \mathrm{e}$ & $3.80 \mathrm{f}$ & $10.00 \mathrm{~d}$ & $1.61 \mathrm{~d}$ & $1.03 \mathrm{e}$ \\
\hline Mean & 275.48 & 4.79 & 5.12 & 13.48 & 2.17 & 1.36 \\
\hline \multicolumn{7}{|c|}{$2^{\text {nd }}$ season } \\
\hline Control & $292.3 \mathrm{a}$ & $4.50 \mathrm{e}$ & $4.33 \mathrm{e}$ & 10.33 ef & $1.56 \mathrm{fg}$ & $1.34 \mathrm{~d}$ \\
\hline NPK & $264.3 \mathrm{c}$ & $6.10 \mathrm{~b}$ & $7.07 \mathrm{a}$ & $22.33 \mathrm{ab}$ & $3.43 \mathrm{~b}$ & $2.59 \mathrm{a}$ \\
\hline $1 / 2 \mathrm{NPK}$ & $258.7 \mathrm{~cd}$ & $4.77 \mathrm{de}$ & $5.73 \mathrm{c}$ & $22.33 \mathrm{ab}$ & $2.38 \mathrm{~d}$ & $1.99 \mathrm{c}$ \\
\hline $1 / 2 \mathrm{NPK}+50 \mathrm{ppm}$ humic acid (HA) & $257.0 \mathrm{~cd}$ & $5.07 \mathrm{~cd}$ & $6.03 \mathrm{bc}$ & $18.00 \mathrm{c}$ & $2.70 \mathrm{c}$ & $2.14 \mathrm{bc}$ \\
\hline $1 / 2 \mathrm{NPK}+100 \mathrm{ppm}$ humic acid (HA) & $255.3 \mathrm{~d}$ & $5.30 \mathrm{c}$ & $6.27 \mathrm{~b}$ & $20.67 \mathrm{~b}$ & $3.42 \mathrm{~b}$ & $2.10 \mathrm{bc}$ \\
\hline $1 / 2 \mathrm{NPK}+150 \mathrm{ppm}$ humic acid (HA) & 244.7 e & $6.70 \mathrm{a}$ & $7.17 \mathrm{a}$ & $23.33 \mathrm{a}$ & $3.72 \mathrm{a}$ & $2.37 \mathrm{ab}$ \\
\hline 50 ppm humic acid & $275.3 \mathrm{~b}$ & 4.33 ef & $4.80 \mathrm{~d}$ & $12.67 \mathrm{e}$ & $1.96 \mathrm{e}$ & $1.04 \mathrm{~d}$ \\
\hline 100 ppm humic acid & $290.6 \mathrm{a}$ & $4.03 \mathrm{f}$ & $4.60 \mathrm{de}$ & $11.00 \mathrm{ef}$ & $1.71 \mathrm{f}$ & $1.04 \mathrm{~d}$ \\
\hline 150 ppm humic acid & $280.3 \mathrm{~b}$ & $3.93 \mathrm{f}$ & $4.50 \mathrm{de}$ & $9.33 \mathrm{f}$ & $1.45 \mathrm{~g}$ & $1.07 \mathrm{~d}$ \\
\hline Mean & 268.7 & 5.00 & 5.61 & 15.89 & 2.48 & 1.74 \\
\hline
\end{tabular}

Means within a column having the same letters are not significantly different according to Duncan's multiple range test

\section{Discussion}

The aforementioned results showed that the treatment of $1 / 2 \mathrm{NPK}+150 \mathrm{ppm}$ humic acid gave the best vegetative growth characters in both seasons followed by the treatment of NPK alone in a few cases. This may be due to the synergistic effect of NPK and humic acid. Nitrogen stimulates stronger green growth, which provides healthy stems and leaves. Phosphorus is a vital nutrient involved in stimulating and enhancing bud development. Potassium plays a main role in plant metabolism as well as enzymes activation for formation of carbohydrate, energy status of the plants, which strengthen the stem. This coincides with the results of El Sallami (2002) on Chorisia speciosa, Leucaena leucocephala and Prosopis juliflora, and El-Naggar and ElNasharty (2009) on amaryllis and Dubey et al. (2017) who mentioned that NPK fertilization treatments significantly increased plant height, number of leaves and suckers per plant. For humic acid, it helps in improving respiration in the growing medium and increasing the water holding capacity (Dorer and Paecock, 1997) in addition to the production of hormone-like activities that improved photosynthesis, phosphorylation, protein synthesis and various enzymatic reactions. However, it reduces inputs of chemical fertilization and minimizes environmental risks (Koreish et al., 2004). It supplies soil with carbon, microbes, increases cell membrane permeability, respiration, photosynthesis, oxygen and phosphorus uptake and helps chelation, and 
improves the effects of mineral fertilizers (Henry, 2011). Atiyeh et al. (2002) reported that the combined application of humic acid and macronutrients helps to transport vital sugars through plant membranes, promotes cell division, cell wall formation, and acts as an enzyme activation in protein.

Table 6. Effect of NPK and humic acid treatments on chemical composition of Erantheumum pulchellum Andrews leaves in two seasons

\begin{tabular}{|c|c|c|c|c|}
\hline Treatments & $\begin{array}{c}\text { Total chlorophyll } \\
\text { (SPAD) }\end{array}$ & $\begin{array}{c}\text { Nitrogen } \\
(\%)\end{array}$ & $\begin{array}{c}\text { Phosphorus } \\
(\%)\end{array}$ & $\begin{array}{c}\text { Potassium } \\
(\%)\end{array}$ \\
\hline \multicolumn{5}{|c|}{$1^{\text {st }}$ season } \\
\hline Control & $31.50 \mathrm{c}$ & $3.68 \mathrm{c}$ & $0.48 \mathrm{~d}$ & $1.29 \mathrm{c}$ \\
\hline NPK & $50.67 \mathrm{ab}$ & $6.01 \mathrm{a}$ & $0.77 \mathrm{ab}$ & $1.96 \mathrm{a}$ \\
\hline $1 / 2$ NPK & $45.83 \mathrm{~b}$ & $4.67 \mathrm{~b}$ & $0.45 \mathrm{~d}$ & $1.64 \mathrm{~b}$ \\
\hline $1 / 2 \mathrm{NPK}+50 \mathrm{ppm}$ humic acid (HA) & $51.33 \mathrm{ab}$ & $4.78 \mathrm{~b}$ & $0.50 \mathrm{~cd}$ & $1.72 \mathrm{ab}$ \\
\hline $1 / 2 \mathrm{NPK}+100 \mathrm{ppm}$ humic acid (HA) & $51.63 \mathrm{ab}$ & $5.13 \mathrm{ab}$ & $0.66 \mathrm{bc}$ & $1.88 \mathrm{ab}$ \\
\hline $1 / 2 \mathrm{NPK}+150 \mathrm{ppm}$ humic acid (HA) & $56.83 \mathrm{a}$ & $5.90 \mathrm{a}$ & $0.92 \mathrm{a}$ & $1.93 \mathrm{a}$ \\
\hline 50 ppm humic acid (HA) & $33.50 \mathrm{c}$ & $3.67 \mathrm{c}$ & $0.35 \mathrm{~d}$ & $1.19 \mathrm{~cd}$ \\
\hline 100 ppm humic acid (HA) & $26.10 \mathrm{c}$ & $3.44 \mathrm{c}$ & $0.45 \mathrm{~d}$ & $1.27 \mathrm{c}$ \\
\hline 150 ppm humic acid (HA) & $26.53 \mathrm{c}$ & $3.26 \mathrm{c}$ & $0.53 \mathrm{~cd}$ & $0.99 \mathrm{~d}$ \\
\hline Mean & 41.54 & 4.50 & 0.57 & 1.54 \\
\hline \multicolumn{5}{|c|}{$2^{\text {nd }}$ season } \\
\hline Control & $32.30 \mathrm{c}$ & $4.02 \mathrm{de}$ & $0.41 \mathrm{f}$ & $1.05 \mathrm{c}$ \\
\hline NPK & $52.60 \mathrm{a}$ & $5.89 \mathrm{ab}$ & $0.91 \mathrm{ab}$ & $1.38 \mathrm{~b}$ \\
\hline $1 / 2 \mathrm{NPK}$ & $47.17 \mathrm{~b}$ & $4.38 \mathrm{de}$ & $0.54 \mathrm{e}$ & $1.17 \mathrm{bc}$ \\
\hline 1/2 NPK + 50 ppm humic acid (HA) & $46.97 \mathrm{~b}$ & $4.78 \mathrm{~cd}$ & $0.73 \mathrm{c}$ & $1.30 \mathrm{~b}$ \\
\hline $1 / 2 \mathrm{NPK}+100 \mathrm{ppm}$ humic acid (HA) & $48.87 \mathrm{~b}$ & $5.48 \mathrm{bc}$ & $0.83 \mathrm{~b}$ & $1.87 \mathrm{a}$ \\
\hline $1 / 2 \mathrm{NPK}+150 \mathrm{ppm}$ humic acid (HA) & $53.20 \mathrm{a}$ & $6.30 \mathrm{a}$ & $1.00 \mathrm{a}$ & $1.93 \mathrm{a}$ \\
\hline $50 \mathrm{ppm}$ humic acid (HA) & $33.87 \mathrm{c}$ & $3.68 \mathrm{e}$ & $0.65 \mathrm{~cd}$ & $1.14 \mathrm{bc}$ \\
\hline 100 ppm humic acid (HA) & $32.87 \mathrm{c}$ & $2.86 \mathrm{f}$ & $0.55 \mathrm{de}$ & $1.10 \mathrm{c}$ \\
\hline 150 ppm humic acid (HA) & $26.80 \mathrm{~d}$ & $1.40 \mathrm{~g}$ & $0.47 \mathrm{ef}$ & $1.08 \mathrm{c}$ \\
\hline Mean & 41.63 & 4.31 & 0.68 & 1.22 \\
\hline
\end{tabular}

Means within a column having the same letters are not significantly different according to Duncan's multiple range test

Stimulatory effect of the treatment $1 / 2$ NPK $+150 \mathrm{ppm}$ humic acid followed in some cases by NPK alone on the fresh and dry weight of the plant is a reflection of the better growth attributes mentioned before. It is well known that nitrogen forms about 40-50\% of dry matter of the plant. Phosphorus has a vital role in photosynthesis and respiration while potassium plays a very important role in regulation of photosynthesis, respiratory rate and increases protein synthesis (Csirzinsky, 1999). This coincides with the results of Hendawy (2008) on Plantago arenaria and Sakr et al. (2018) on Pelargonium graveolens.

Regarding the promotive effect of humic acid, it affects growth through producing hormone analogues or growth regulators (Albayrak and Camas, 2005). Moreover, Sathiyabama and Selvakumari (2001) mentioned that application of $10 \mathrm{~kg} / \mathrm{ha}$ humic acid, along with $75 \%$ of the recommended NPK dose was found to significantly influence production of green matter of Amaranthus. 
The mentioned results, concluded that the rooting parameters (root length, root number and fresh and dry weighs of roots) significantly responded to the treatment of $1 / 2$ NPK $+100 \mathrm{ppm}$ humic acid and then in a few cases to the treatment NPK alone. This is explained in the view that nitrogen stimulates vegetative growth, which reflects on better root growth. Root stimulating fertilizers are often higher in phosphorus as it helps strengthen young roots and give them a strong start (Ayemi et al., 2017). As for humic acid which includes microorganisms capable of producing plant growth regulators such as auxins, gibberellins, cytokinins, etc. and also buffers the hydrogen ion $(\mathrm{pH})$ concentration of the soil as attained by several workers as Mohammad Ipour et al. (2013) on pot marigold and Boogar et al. (2014) on Petunia hybrida.

The stimulatory effect of NPK on flowering was well known as nitrogen is a main constituent of chlorophyll leading to effective photosynthesis process with more carbohydrates necessary for flowering. Phosphorus is the element most responsible for stimulating stronger bud and flower development (Ayemi et al., 2017) and potassium is vital to several areas of plant growth as photosynthesis and metabolism, etc. including drought tolerance, disease resistance, stem strength, improved texture, colour and photosynthesis. Ahmed et al. (2010) reported that NPK treatments increased number of flowers per plant, fresh and dry weights of flower reached maximum with 15:20:10 NPK application in African marigold and 15:10:10 in French marigold. Similarly, were the results of EL-Naggar et al. (2016) on Anthurium andreanum and Ayemi et al. (2017) who demonstrated that Gerbera cv Ruby Red responded to NPK fertilization treatments in terms of number of flowers per plant, days to first flower appearance, flower diameter, stalk length and diameter and vase life of flowers.

The simulative effects of humic acid on plant growth was previously discussed and are supported by the findings of Dudley et al. (2004) on Zinnia elegans (Memon et al., 2014) on Petunia multiflora. As for the synergistic effect of humic acid due to partitioning of NPK with it, Ibrahim et al. (2014) mentioned that the significantly highest values of enhanced growth, flowering and quality of wild garlic plants, resulted from the treatment of $2 \mathrm{ml}$ humic acid $+1 \mathrm{~g} /$ pot NPK (10:10:10).

Briefly it is a must to maximize from the synergistic effect of humic acid to reduce the risk of chemical minerals on environment as well as their high costs from the economical point of view as the treatment of $1 / 2 \mathrm{NPK}+150 \mathrm{ppm}$ humic acid seems to be the best in this concern. Moreover, the application of humic acid alone gave close values or even less than control in all studied characters as failed to compensate the effect of NPK at anyhow.

This is logical since nitrogen is a main constituent of chlorophyll molecule and has a great role to form protein, which affects forming of chlorophyll. Also, phosphorus is vital in photosynthesis and respiration. Potassium affects many functions in plant like regulating photosynthesis, respiratory rate and increases protein synthesis by Hasio and Lauchi (1986).

The data in Table 6 were in agreement with the findings of the synergistic effects of humic acid due to its beneficial effects associated with elevated tissue concentration of macronutrients. This was attained by Boogar et al. (2014) on Petunia hybrida L and Ibrahim et al. (2014) on Tulbaghiavi oleracea L and Sakr et al. (2018) on Pelargonium graveolens.

The results were a reflection of the promotive effect of NPK and humic acid on the various vegetative, rooting and chlorophyll characters leading to more accumulation of dry matter in the leaves. These results were confirmed by the findings of Darwish 
(2008) on Casuarina glauca and Sayed et al. (2010) on Vinca rosea c.v Major who indicated that all NPK treatments increased the leaf content of chlorophyll $a$ and $b$ and $\mathrm{N}, \mathrm{P}$ and $\mathrm{K} \%$.

Humic acid helps the soil to retain the nutrients making plants healthier and less susceptible to insect and disease problems (Henry, 2011). These results were supported by those of Ibrahim et al. (2014) on Tulbaghiavi oleracea L. who mentioned that application of humic acid at $9 \mathrm{~cm} / 1$ as soil drench increased chlorophyll (a) and (b), content, $\mathrm{N}, \mathrm{P}$ and $\mathrm{K} \%$ in the leaves compared to untreated plants.

\section{Conclusion}

From the aforementioned results, it is recommended to fertilize the Erantheumum pulchellum plant with half dose of NPK $(3 \mathrm{~g}$ ammonium sulphat $2 \mathrm{~g}$ calcium super phosphate $+1.5 \mathrm{~g}$ potassium sulphat) plus spraying plants with $150 \mathrm{ppm}$ humic acid for each/pot to minimize the risk of the pollution due to chemical fertilization. Calcium super phosphate should be applied at preparing of the soil while $\mathrm{N}$ and $\mathrm{K}$ as well as spraying humic acid should be applied monthly during the growing season to obtain the high quality vegetative, rooting and flowering characteristics of the plants.

\section{REFERENCES}

[1] Ahmed I., Asif, M., Amjad, A., Ahmed, S. (2010): Fertilization enhances growth, yield, and xanthophyll contents of marigold. - Turk J Agric. For. 35: 641-648.

[2] Albayrak, S., Camas, N. (2005): Effects of different levels and application times of humic acid and leaf yield and yield components of forage turnip (Brassica rapa L.). - J. Agron. 4: 130-133.

[3] Atiyeh, R. M., Edwards, C. A., Metzger, J. D., Lee, S., Arancon, N. Q. (2002): The influence of humic acids derived from earth worm processed organic wastes on plant growth. - Bioresour. Technol. 84: 7-14.

[4] Ayemi, T. J., Sing, D., Fatmi, U. (2017): Effect of NPK on plant growth, flower quality and yield of Gerbera (Gerbera jamesonii L.) cv. Ruby Red under. naturally ventilated polyhouse condition. - International Journal of Current Microbiology and Applied Sciences 6(8): 1049-1056.

[5] Black, C. A. (1983): Method of Soil Analysis. A Part 1 and 2. - Soil Sci. Soc Amer. Inc., Madison, WI.

[6] Boogar, A. R., Ebrahim, S., Abolfazl, G. (2014): Effect of humic acid application on qualitative characteristic and micronutrient status in Petunia hybrida L. - Bull. Env. Pharmacol. Life Sci. 3(9): 15-19.

[7] Csirzinsky, A. A. (1999): Yield response of herbs to N and K in sand in multiple harvests. - J Herbs, Spices and Medic. Plants. 6(4): 11-22.

[8] Darwish, M. A. (2008): Effect of biofertilizers, NPK and humic acid on growth and chemical composition of Casuarina glauca Sieber seedlings. - J. Product Dev. 13(3): 507-522.

[9] Devlin, R. M. (1975): Plant Physiology. - Affiliated East West Press, New Delhi, pp. 159-205.

[10] Dorer, S. P., Paecock, C. H. (1997): The effect of humate and organic fertilizer on establishment and nutrition of creeping bentgrass putting greens. - Inter. Turfgrass Soc. Res. J. 8: 437-443.

[11] Dubey, A. K., Singh, D., Rajput, P. S., Kumar, Y., Verma, A. K., Chandraker, S. K. (2017): Effect of NPK on plant growth, yield and quality of Capsicum (Capsicum annum 
L.) c. v. Swarna under shade net condition. - International Journal of Current Microbiology and Applied Sciences 6(3): 1085-1091.

[12] Dudley, J. B., Pertuit, A. J., Toler, J. E. (2004): Leonardite influences zinnia and marigold growth. - Hort Sci. 39(2): 251-255.

[13] Duncan, D. B. (1955): Multiple Range and Multiple F-Test. - Biometrics 11: 1-42.

[14] Edward F. G. (1999): One of a Series of the Environmental Horticulture Department. Florida Cooperative Extension Service, Institute of Food and Agricultural Sci, Univ of Florida.

[15] El-Naggar, A. H., El-Nasharty, A. B. (2009): Effect of growing media and mineral fertilization on growth, flowering, bulbs productivity and chemical constituents of Hippeastrum vittatum. - American-Eurasian J. Agric. and Environ. Sci. 6(3): 360-371.

[16] El-Naggar, A. H., Naglaa, E. M., El-Naggar, A. A. (2016): Effect of mineral and biofertilization on vegetative growth and flowering of Anthurium andreanum L. plants under greenhouse conditions. - J. Alex. Sci. Exch. 37(1): 1-9.

[17] El-Sallami, I. H. (2002): Seedling response of some ornamental trees to soil type and NPK fertilization. - Assuit. J. Agric. Sci. 33(3): 49-83.

[18] Hasio, T. C., Lauchli, A. (1986): A Role of Potassium in Plant-Water Relations. - In: Tinker, P. B. A. (ed.) Advances in Plant Nutrition. Vol. 2. Praeger Sci, New York, pp. 281-311.

[19] Hendawy, S. F. (2008): Comparative study of organic and mineral fertilization on Plantago arenaria plant. - J. App. Sci. Res. 4(5): 500-506.

[20] Henry, T. (2011): Spring is a true re-constructionist. - J\&L Garden Center's News. http://jlgardencenter.com/news/11/15.

[21] Ibrahim, H. E., Abdel-Moniem, A., El-Foly, S. A. (2014): Effect of some fertilization treatments on growth, flowering and chemical composition of wild garlic (Tulbaghia violavea L.) plant. - J. Biol. Chem. Environ. Sci. 9(4): 165-180.

[22] Jackson, M. L. (1967): Soil Chemical Analysis. - Prentice Hall, Inc., Englewood Cliffs.

[23] King, E. J. (1951): Micro Analysis in Medical Biochemistry. $2^{\text {nd }}$ Ed. - Churchill, London.

[24] Koreish, E. A., El-Fayoumy, M. E., Ramadan, H. M., Mohamed, W. H. (2004): Interaction effect of organic and mineral fertilization on faba bean and wheat productivity in calcareous soils. - Alex. J. Agric. Res. 2: 101-114.

[25] Memon, S. A., Baloch, M. H., Baloch, R. A. (2014): Influence of humic acid and macronutrients (MgSO4 $+\mathrm{S}$ ) application on growth and yield of petunia (Petunia multiflora). - Journal of Agricultural Technology 10(6): 1501-1516.

[26] Mohammadipour, E., Golchin, A., Mohammadi, J., Negahdar, N., Zarchini, M. (2013): Effect of humic acid on yield and quality of pot marigold (Calendula officinalis L.). Ann. Biolog. Res. 3(11): 5095-5098.

[27] Nikbakht, A., Kafi, M., Babalar, M., Xia, Y. P., Luo, A., Etemadi, N. (2008): Effect of humic acid on plant growth, nutrient uptake, and postharvest life of gerbera. - Journal of Plant Nutrition 31: 2155-2167.

[28] Pal, A. L., Biswas, B. (2005): Response of fertilizer on the growth and yield of tuberose (Polianthes tuberosa) cv. Calcutta Single in the plants of West Bengal. - Inter Academicia 9(1): 33-36.

[29] Sakr, W. R. A., El-Sayed, A. A., Hammouda, A. M., Saad El Deen, F. S. A. (2018): Effect of NPK, Aloe gel and Moringa extracts on geranium plants. - Journal of Horticultural Science \& Ornamental Plants 10(1): 1-16.

[30] Sathiyabama, K., Selvakumari, G. (2001): Effect of humic acid on growth, yield and nutrition of Amaranthus. - South-Indian-Hort. 49: 155-156.

[31] Sayed, B. A., Samira, S. A., Shahin, S. M. (2010): Response of Vinca rosea cv. Major plant to chemical and biofertilization treatments. - J Biol. Chem Environ. Sci. 5(4): 2538 . 
[32] Sharif, M., Khattak, R. A., Sarir, M. S. (2002): Effect of different levels of lignitic coal derived humic acid on growth of maize plants. - Communic Soil Sci and Plant Analy 33: 3567-3580.

[33] Sendecor, G. W., Cochran, W. G. (1980): Statistical Methods. 6th Ed. - Iowa State Univ. Press, Ames, IA.

[34] Stevenson, F. J. (1994): Humus Chemistry: Genesis, Composition, Reactions. - Wiley, New York.

[35] Stott, D. E., Martin, J. P. (1990): Synthesis and Degradation of Natural and Synthetic Humic Material in Soils. - In: MacCarthy, P., Clapp, C. E., Malcolm, R. L., Bloom, P. R. Humic Substances in Soil and Crop Sciences: Selected Readings. SSSA, Madison, WI, pp. 37-64.

[36] Yadava, U. L. (1986): A rapid and nondestructive method to determine chlorophyll in intact leaves. - Hort. Sci. 21(6): 1449-1450. 